\title{
EVALUATION OF NUTRITION HABITS OF ADOLESCENTS IN THE ASPECT OF GENDER AND PHYSICAL ACTIVITY
}

\author{
Daiva Vizbaraitė, Rasa Jankauskienė, Aušra Griciūtė, Kristina Visagurskienė, Simona Pajaujienė \\ Lithuanian Academy of Physical Education, Kaunas, Lithuania
}

\begin{abstract}
Research background and hypothesis. Nutrition habits develop with the growth of an individual. During adolescence proper nutrition habits and physical activity are the most important factors influencing health. The quality of life is affected by the peculiarities of behavior and lifestyle in adolescence.

The aim of our study was to determine nutrition habits of adolescents, and then, to make a comparison of eating patterns by gender and the groups of adolescents in different physical activity groups.

Research methods. The study comprised the ninth form students from 16 Kaunas schools (4 gymnasiums, 10 secondary and 2 main schools). The strategy was based on the evaluation of proportions of the different types of schools in Kaunas. The study applied questionnaire survey.

Research results. The analysis revealed that $28.5 \%$ of middle-school age students did not have breakfast, there were more girls than boys among them. Boys and students with lower physical activity more frequently had hot meals. Adolescents most commonly had meals four times per day without following nutrition regimen.

Discussion and conclusions. Boys more frequently had breakfast, however, they chose buns, potato chips, and used more fried food for snacks; the same eating patterns were followed by students with lower physical activity. Girls were more likely to have fruit, green vegetables. In most cases, the selection of meals depended on the individual taste; boys more frequently paid attention to prices and nutrition values. Usually adolescents acquired information about proper nutrition from their parents and the internet; girls - more frequently from magazines and the internet.
\end{abstract}

Keywords: adolescents' knowledge on healthy nutrition, nutrition habits, physical activity.

\section{INTRODUCTION}

$\mathrm{N}$ utrition habits and physical activity are the most significant factors influencing health during adolescence. Namely, these factors may reduce the risk of chronic diseases, improve health and work capacity (Boreham, Riddoch, 2001; Grinienè, 2003). Child and adolescent obesity is also a relevant problem in the world, thus the main focus is on the prevention obesity among young people. Knowledge and lifestyle are becoming important. It is relevant to increase adolescent physical activity and change nutrition habits, reduce the time spent on watching TV and using computer (Perez et al., 2011). The use of appropriate health programs and methods in schools encouraging students to change their lifestyle is relevant (Hardy et al., 2011). Currently, 
in the European Union the main concern is about the trends of nutrition and physical activity as well as health enhancement.

Studies show that physical activity and change of nutrition habits provide positive results and are effective means of control of obesity (overweight) (Ezendam et al., 2011).

When compared to boys, girls have healthier diets: they are more likely to have fruit, green vegetables, and less likely - potato chips, fried potatoes, Coke or other sweet drinks, as well as alcoholic beverages, however, they eat sweets and chocolate more frequently (Zaborskis et al., 2006).

Some studies show that more physically active adolescents evaluate their nutrition more positively, thus, their nutrition is healthier (Petronyte, Vizbaraitè, 2005).

The studies performed in Lithuania reveal that although Lithuania belongs to the countries where school-age students spend much time watching $\mathrm{TV}$, eat little fruit, often experience abuse, there are also some positive facts, such as the lowest prevalence of overweight, a small number of adolescents reported drinking Coke and other sweetened carbonated drinks. However, the student population was also marked by unfavorable trends of lifestyle, thus it is necessary to design and implement health programs, which would have a positive influence on student lifestyle (Zaborskis, 2010)

Our hypothesis that nutrition habits and knowledge about nutrition are better (healthier) among girls and thoses who had a higher level of physical activity than among boys and students with a lower physical activity levels was based on the previuosly performed studies.

The aim of the study was to determine nutrition habits of adolescents, and to make a comparison of eating patterns by gender and belonging to different physical activity groups.

\section{RESEARCH METHODS}

The study was carried out in September and October, 2010.

The subjects. The ninth form students participated in the study from 16 schools in Kaunas (4 gymnasiums, 10 secondary schools and 2 main schools). The sampling strategy was based on the proportions between the different types of schools. Overall 579 questionnaires were disseminated. Not all questionnaires were filled in, thus the data of 464 questionnaires were used for statistical analysis (girls $\mathrm{n}=236$, boys $\mathrm{n}=228$ ). The mean age of the subjects (SD) was $14.98(0.41)$ years. The youngest participant was 14 years old, the oldest -17 years old.

The study employed anonymous questionnaire survey; the consent from school as well as students and their parents was obtained.

The questionnaire. The rate of student exercising was determined by a modified Leisure Time Exercise Questionnaire (LTEQ, Godin, Shephard, 1985). Respondents were asked to point out their low, moderate and high intensity of exercising expressed by times per week if the duration of exercises was longer than 15 minutes. These times were compared to metabolic equivalents of 3,5 and 9 , respectively, and later on, the scores of all intensity levels were added together. The LTEQ instructions include the examples of physical activity that were adapted to the Lithuanian adolescent physical activity. Several studies have revealed that LTEQ questionnaire is reliable and valid (Jacobs et al., 1993). The physical activity in the leisure time (not during classes of the sample) had 57 (32.37) scores (MET/wk). The lowest physical activity was given 0 points, the highest -259 points. Accordingly the subjects were classified into two groups: of lower and higher physical activity.

The questionnaire of nutrition habits was prepared referring to the methodology of the previous studies (Petronyte, Vizbaraitè, 2005). The respondents were asked to report the following: how many times per day they had meals, if they followed nutrition regimen, what kind of products they chose, what influenced their choice, where they acquired information about healthy nutrition.

The results of the study were compared between the groups of girls and boys as well as between the groups of higher and lower physical activity.

Statistical analysis. The data were analyzed using SPSS for Windows 13.0 (Statistical Package for Social Science 13 for Windows). Qualitative determinants were evaluated by chi square criterion. The results were considered statistically significant if $\mathrm{p}<0.05$.

\section{RESEARCH RESULTS}

The results of the analysis revealed that $28.5 \%$ of students rarely or never had breakfast; there were 
Table. Distribution of girls, boys and groups of different physical activity (PA) by nutrition habits

\begin{tabular}{|l|c|c|c|c|c|c|c|c|c|c|}
\hline \multicolumn{1}{|c|}{ Feature } & Girls, \% & Boys, \% & $\chi^{2}$ & df & $\mathbf{p}$ & $\begin{array}{c}\text { Higher PA, } \\
\text { \% }\end{array}$ & $\begin{array}{c}\text { Lower PA, } \\
\%\end{array}$ & $\chi^{2}$ & df & p \\
\hline $\begin{array}{l}\text { Rarely or never have } \\
\text { breakfast }\end{array}$ & 7.4 & 4.5 & 9.19 & 3 & 0.03 & 7.9 & 6.4 & 0.416 & 1 & 0.519 \\
\hline Hot breakfast & 21.1 & 28.9 & 4.64 & 1 & 0.03 & 20.2 & 28.4 & 4.247 & 1 & 0.039 \\
\hline $\begin{array}{l}\text { Consumption of buns } \\
\text { as snacks }\end{array}$ & 35.9 & 56.5 & 16.16 & 1 & 0.001 & 43.2 & 53.2 & 4.637 & 1 & 0.031 \\
\hline $\begin{array}{l}\text { Consumption of } \\
\text { vegetables and fruit } \\
\text { as snacks }\end{array}$ & 32.6 & 22.9 & 6.61 & 1 & 0.01 & 29.5 & 26.6 & 0.495 & 1 & 0.482 \\
\hline $\begin{array}{l}\text { Meals taken at the } \\
\text { same time }\end{array}$ & 14.14 & 21.8 & 5.30 & 1 & 0.03 & 18.9 & 15.7 & 0.8231 & 1 & 0.364 \\
\hline $\begin{array}{l}\text { Frequent } \\
\text { consumption of fried } \\
\text { foods }\end{array}$ & 64.2 & 76.9 & 11.03 & 1 & 0.001 & 66.8 & 76.6 & 5.47 & 1 & 0.02 \\
\hline $\begin{array}{l}\text { Consumption of } \\
\text { smoked foods }\end{array}$ & 3 & 9.9 & 11.24 & 1 & 0.001 & 6.2 & 5.5 & 0.092 & 1 & 0.762 \\
\hline $\begin{array}{l}\text { Frequent } \\
\text { consumption of } \\
\text { brown bread }\end{array}$ & 40.9 & 49.3 & 4.34 & 1 & 0.04 & 41.9 & 50.6 & 3.97 & 1 & 0.058 \\
\hline
\end{tabular}

more girls than boys, $7.4 \%$ and $4.5 \%$, respectively, $\chi^{2}=9.19 ; \mathrm{df}=3 ; \mathrm{p}=0.03$. The responses of lower or higher physical activity groups did not differ significantly (Table).

Hot breakfast was chosen by $24.5 \%$ of students, by more boys then girls: 28.9 and $21.1 \%$, respectively, $\chi^{2}=4.64 ; \mathrm{df}=1 ; \mathrm{p}=0.03$. The students of lower physical activity group more frequently had hot breakfast compared to the group of higher physical activity, 20.2 and $28.4 \%$, respectively, $\chi^{2}=4.24 ; \mathrm{df}=1 ; \mathrm{p}=0.039$ (Table).

Only $39.2 \%$ of students reported having soup and the second course, $34.4 \%$ - most commonly had only the second course. The respondents (13\%) pointed out that they had only snacks instead of lunch. About $3.8 \%$ of students did not have snacks between meals. Buns as snacks were chosen by $47.5 \%$ of respondents; most were boys among them -56.5 and $35.9 \%$, respectively, $\chi^{2}=16.16$; $\mathrm{df}=1 ; \mathrm{p}=0.0001$. The students with lower physical activity also reported having more frequently buns as snacks, 53.2 and $43.2 \%$, respectively, $\chi^{2}=4.63$; df $=1 ; p=0.031$. Vegetables and fruit as the most common snacks were reported by $27.6 \%$ of adolescents, more were girls than boys, 32.6 and $22.9 \%$, respectively, $\chi^{2}=6.61 ; \mathrm{df}=1 ; \mathrm{p}=0.01$. Chocolate and potato chips were marked as snacks by $17.3 \%$ of students, the responses did not differ by gender, $\chi^{2}=0.05 ; \mathrm{df}=1 ; \mathrm{p}=0.83$. Difference among the students in the groups of different physical activity was not detected (Table).

Barely $17.8 \%$ of students reported having their meal at the same time, among them there were more boys than girls, 21.8 and $14.14 \%$, respectively, $\chi^{2}=5.30 ; \mathrm{df}=1 ; \mathrm{p}=0.03$. The responses did not differ between the groups of different physical activity $\left(\chi^{2}=0.823 ; \mathrm{df}=1 ; \mathrm{p}=0.364\right)$.

The adolescents responded that they had their meals 3.89 times per day on average. Boys had meals more frequently than girls, 4.14 and 3.67 times per day, respectively, $p=0.0001$. Frequent intake of food between meals was reported by $41.3 \%$ of students. We did not determine the differences by gender and by groups of physical activity.

Almost $69.1 \%$ of students pointed out that they most frequently consumed fried foods, there were more boys were than girls, 76.9 and $64.2 \%$, respectively, $\chi^{2}=11.03 ; \mathrm{df}=1 ; \mathrm{p}=0.001$. The students of lower physical activity had an intake of fried foods more frequently compared to the students of higher physical activity, 76.6 and $66.8 \%$, respectively, $\chi^{2}=5.47 ; \mathrm{df}=1 ; \mathrm{p}=0.02$ (Table). Boys reported having smoked foods more frequently, 9.9 and $3 \%$, respectively, $\chi^{2}=11.24$; $\mathrm{df}=1 ; \mathrm{p}=0.001$. We did not detect differences in having boiled food by gender. Girls more frequently than boys pointed out that they were having steamed food, 24 and $16.5 \%$, respectively, $\chi^{2}=4.93 ; \mathrm{df}=1 ; \mathrm{p}=0.03$.

The majority of students $(68.6 \%)$ reported that they had food prepared using oil, but no differences by gender were found. Nevertheless, $30.6 \%$ of students reported having butter more frequently, more boys than girls among them, 35.3 and $26.8 \%$, respectively, $\chi^{2}=4.76 ; \mathrm{df}=1 ; \mathrm{p}=0.03$. Differences 

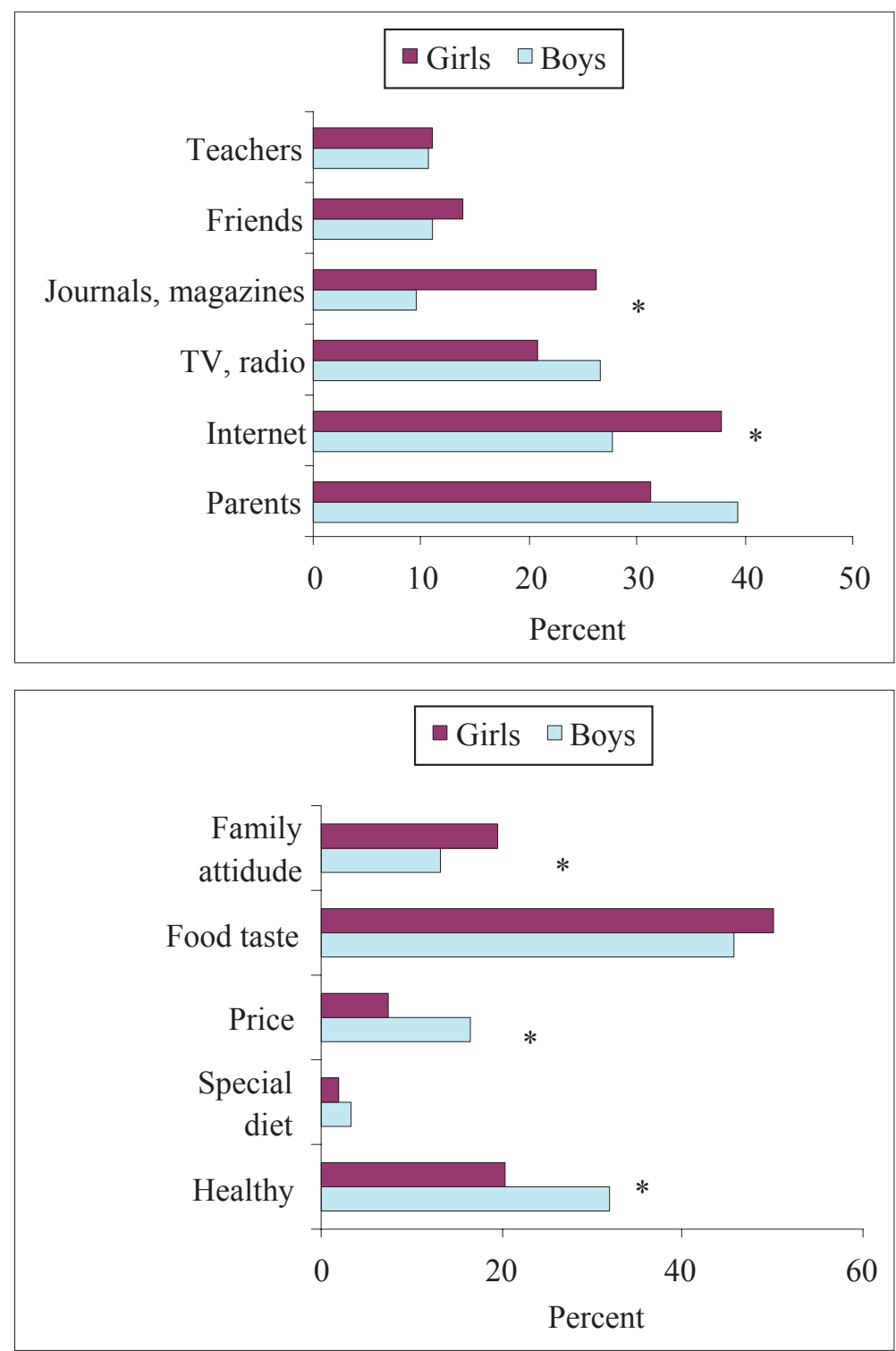

Figure 1. Sources of information about healthy nutrition

Note. $*-p<0.05$.

Figure 2. Criteria of respondents for food selection

Note. ${ }^{*}-\mathrm{p}<0.05$. between the groups of different physical activity were not determined. Barely $13.6 \%$ of students pointed out that they had cracked grain bread, we did not detect any differences by gender. A greater number of respondents $(44.2 \%)$ pointed out that they more frequently consumed brown bread, there were more boys than girls, 49.3 and $40.9 \%$, respectively, $\chi^{2}=4.34 ; \mathrm{df}=1 ; \mathrm{p}=0.04$. White bread was chosen by $33.9 \%$ of students, $23.4 \%$ of them reported consuming long loaf more frequently. We did not detect differences by gender and groups of physical activity.

The subjects $(34.4 \%)$ pointed out that mostly they gained knowledge about nutrition from their parents, internet ranked second (33.1), TV and radio were in the third place followed by magazines $(18.3 \%)$, then friends $(12.5 \%)$, and finally, teachers and school staff were only in fifth position $(10.9 \%)$. More girls found information in the internet, 37.9 and $27.8 \%$, respectively, $\chi^{2}=6.58 ; \mathrm{df}=1 ; \mathrm{p}=0.01$. As it was expected, more girls reported finding information in magazines 26.2 and $9.6 \%$, respectively, $\chi^{2}=25.9$; $\mathrm{df}=1 ; \mathrm{p}=0.001$ (Figure 1). We did not determine differences between groups of different physical activity.

Every second student (48\%) reported that food selection was most commonly based on food taste properties, $25.9 \%$ - on nutritional value, $16.5 \%$ of students thought that their selection was based on family attitudes, and $11.7 \%$ pointed out the price of food. Unexpectedly, nutritional value was more stressed by boys 31.9 and $20.5 \%$, respectively, $\chi^{2}=9.64 ; \mathrm{df}=1 ; \mathrm{p}=0.002$. Girls more frequently admitted that food selection was influenced by the attitudes of their families 19.5 and $13.2 \%$, respectively, $\chi^{2}=4.08 ; \mathrm{df}=1 ; \mathrm{p}=0.04$, while boys more frequently than girls reported that their selection of food was also affected by price 16.5 and $7.4 \%$, respectively, $\chi^{2}=11.39 ; \mathrm{df}=1$; 
$p=0.001$. We did not detect differences between the groups of different physical activity.

When students were asked to mark three main principles of healthy nutrition, they mostly stressed a balanced diet (75.1\%), ecological food $(58.1 \%)$, and a variety of food $(56.9 \%)$. Moderate in food consumption was marked by $54.3 \%$ of students. We did not detect differences by gender and groups of different physical activity.

Only $6.5 \%$ of students reported following the requirements of healthy nutrition all the time, while $18.1 \%$ of school-age students admitted that they never followed these requirements. We did not find differences by gender or by groups of physical activity. Students $(41.1 \%)$ responded that they had vegetables every day, only $36.8 \%$ ate fruit and berries. Only $51.8 \%$ of students had grains (bread, grits, cereals) every day. However, almost $32.2 \%$ of students had confectionery every day, $18 \%$ of them reported having sweet drinks (lemonade, Coke ant others) every day. We did not find differences by gender and groups of physical activity.

\section{DISCUSSION}

We wanted to find out the following issues: what were the adolescent nutrition habits, whether they differed among boys and girls and in the groups of different physical activity, which criteria for food selection were chosen by them, which sources of information assisted in the choice of food. The analysis revealed that almost $28.5 \%$ of students did not have breakfast, there were more girls than boys. Boys and students of lower physical activity group reported having hot breakfast more frequently $(p<0.05)$. Studies performed by other scientists demonstrated a similar trend, i. e., only approximately $63 \%$ of students had breakfast regularly. Hot dinner was selected by $60 \%$ of school-age students, intake of fruit every day was pointed out by $65.5 \%$, consumption of vegetables $30.9 \%$ (Vitariusova et al., 2010).

Approximately $13 \%$ of the respondents reported that they had snacks instead of lunch, and the most popular snacks were buns (47.5\%). More frequently, buns as snacks were selected by boys and students of lower physical activity $(\mathrm{p}<0.05)$.

The analysis of selection of foods as snacks by girls showed that their nutrition was healthier. Girls were more likely to consume fruit, green vegetables than boys, and they had less potato chips, fried potatoes, sweet drinks. Such trends were also determined in previous studies (Zaborskis et al., 2006).

Our subjects reported that they commonly had four meals per day, on average. The previous studies showed that students of similar age, as most Lithuanian residents, pointed out that they had three meals per day, on average (Kadziauskienė et al., 1999; Grabauskas, 2004; Zaborskis, 2005). As most adolescents, our subjects did not follow nutrition regimen. Only $17.8 \%$ of students reported having their meals at the same time, among them there were more boys than girls $(\mathrm{p}<0.05)$.

Other researchers have also determined that adolescents had nutrition problems, thus it is necessary to change their eating habits. The number of overweight students is slowly increasing, particularly, of those who live in towns. These students more rarely had their meals at home, and more frequently, used confectionery and potato chips (Kukulu et al., 2010). The boys and students with lower physical activity in our study used more foods fried in oil. Therefore, their nutrition is not healthier than that of girls or students of higher physical activity.

Answering the question about oil selection, our subjects reported oil as most common for cooking food (Kadziauskienè et al., 1999; Petronyte, Vizbaraitè, 2005).

There is a lack of healthy grain food in the ration of our students, only few of them pointed out that they ate cracked grain bread or brown bread. Moreover, only $6.5 \%$ of students reported following the healthy nutrition requirements. When comparing the results with studies carried out in other countries, few students drank Coke and other sweet drinks, but they did not exclude confectionery from their food ration (Zaborskis, 2005; Strukčinskienè, 2009).

Knowledge and information that may influence adolescents are very important for the development of nutrition habits. It is especially important of the younger age, since some authors associate obesity in the older age with the lack of knowledge (al Riyami et al., 2010). There are interesting results about the sources of information that differed from the previous studies. According to the previous studies, students reported that they received most information from TV and friends, while our students pointed out that they obtained such knowledge from their parents (Petronyte, Vizbaraitè 2005). 
Food selection criteria were similar as in the previous studies, however, they differed from the opinion poll of Lithuanian residents, who were more likely to choose foods according to the price (Kadziauskienè et al., 1999; Petronytè, Vizbaraite 2005). Our subjects most frequently selected food by taste $(47.9 \%)$, the criterion of nutrition value was important for boys, while for girls it was family attitude $(p<0.05)$. The evaluation of responses to questions about healthy nutrition and the principles of healthy nutrition reveals that there is still a lack of information and knowledge about these issues. The hypothesis that nutrition of girls and school-age students with higher PA is healthier cannot be entirely confirmed on the basis of our studies. Girls selected healthier snacks, however, they did not follow nutrition regimen. No significant differences were found between PA groups. Moreover, we can state that health education programs where adolescents would acquire knowledge about healthy lifestyle in an popular way, are necessary. This program should last longer until healthy habits have been formed. This is confirmed by other studies (Siega-Riz et al., 2011).

\section{CONCLUSIONS AND PERSPECTIVES}

Most often adolescents had their meals four times per day. Boys had breakfast more frequently, however, they selected buns and potato chips as snacks, and they consumed more fried foods, the same pattern was observed in the groups with lower physical activity. Girls were more likely to choose fruit and green vegetables as snacks. Mostly students selected their meals by taste, and boys - more frequently by price and nutrition value. Adolescents most often received information about healthy nutrition from parents and the internet, and girls - from magazines and internet more frequently than boys.

\section{REFERENCES}

Boreham, C., Riddoch, C. (2001). The physical activity, fitness and health of children. Journal of Sports Sciences, 19, 915-929.

Ezendam, N. P., Springer, A. E., Brug, J., Oenema, A., Hoelscher, D. H. (2011). Do trends in physical activity, sedentary, and dietary behaviors support trents in obesity prevalence in 2 border regions in Texas? Journal of Nutrition Education and Behavior, 2 (9) 223-229.

Grabauskas, V., Petkevičienè, J., Kriaučionienè, V., Klumbiené, J. (2004). Lietuvos gyventojų sveikatos skirtumai: išsimokslinimas ir mitybos ipročiai. Medicina. $40(9), 875-883$.

Griniene, E. (2003). Paaugliu fizinis aktyvumas, sveikata ir sveika elgsena. Dvasinès vertybès žiniu visuomenèje: tarptautinès mokslinès konferencijos mokslo darbai (pp. 211-114). Kaunas.

Hardy, L. L., King, L., Espinel, P., Okely, A. D., Bauman, A. (2011). Methods of the NSW Schools Physical Activity and Nutrition Survey 2010 (SPANS 2010). Journal of Science and Medicine in Sport, 3-30.

Kadziauskienė, K., Bartkevičiūtè, R., Olechovič, M. et al. (1999). Suaugusiu Lietuvos žmoniu gyvensenos ir faktiškos mitybos tyrimas. Vilnius: Respublikinis mitybos centras.

Kukulu, K., Sarvan, S., Muslu, L., Yirmibesoglu, S. G. (2010). Dietary habits, economic status, academic performance and body mass index in school children: A comparative study. Journal of Child Health Care, 14 (4), 355-366.

Perez, A., Hoelscher, D. M., Springer, A. E. et al. (2011). Physical activity, watching television, and the risk of besity in Rtudents, Texas, 2004-2005. Preventing Chronic Discase, 8 (3) 61-76.

Petronytè, G., Vizbaraitè, D. (2005). 14-18 metų mokiniu mitybos ir fizinio aktyvumo sąsaja. Visuomenès sveikata, 3 (30), 41-45.

Al Riyami, A., Al Hadabi, S., Abd El Aly M. A. et al. (2010). Nutrition knowledge, beliefs and dietary habits among elderly people in Nizwa, Oman: Implications for policy. East Mediterranean Health Journal, 16 (8), 859-867.

Siega-Riz, A. M., E. L. Ghormli, L., Mobley, C. et al. (2011). The effects of the Healthy study intervention on middle school student dietary intakes. International Journal of Behavioral Nutrition and Physical Activity, 8 (1), 7-9.

Strukčinskienė, B. (2009). Šilutès rajono savivaldybès mokyklinio amžiaus vaiku gyvensenos tyrimas. Klaipèdos universitetas: Šilutès rajono savivaldybès Visuomenès sveikatos biuras.

Vitariusova, E., Babinska, K., Kostalova, L. et al. (2010). Food intake, leisure time activities and the prevalence of obesity in schoolchildren in Slovakia. Central European Journal of Public Health, 18 (4), 192-197.

Zaborskis, A. (2005). Lietuvos moksleiviu gyvensenos vertinimas 1994-2002 metais/HEALTH BEHAVIOUR OF LITHUANIAN SCHOOL CHILDREN IN 1994-2002. Lietuvos bendrosios praktikos gydytojas, 9, 326-333.

Zaborskis, A., Petronyte, G., Buitvydaitè, R. et al. (2006). Lietuvos vyresniuju klasių moksleivių mitybos ipročiu netolygumai. Visuomenés sveikata, 4, 40-44. 


\title{
PAAUGLIŲ MITYBOS İROČIŲ VERTINIMAS LYTIES IR FZINIO AKTYVUMO POŽIŪRIU
}

\author{
Daiva Vizbaraitė, Rasa Jankauskienė, Aušra Griciūtė, Kristina Visagurskienė, Simona Pajaujienė \\ Lietuvos kūno kultūros akademija, Kaunas, Lietuva
}

\section{SANTRAUKA}

Tyrimo pagrindimas ir hipotezė. Mitybos ipročiai susiformuoja augant. Tinkami mitybos ipročiai ir fizinis aktyvumas paauglysteje, kai organizmas sparčiai vystosi, yra vieni iš svarbiausiu sveikatą lemiančių veiksnių. Nuo paauglystès elgsenos ir gyvensenos ypatumu, požiūrio i̇ sveikatą priklauso vèlesnio gyvenimo kokybè.

Tikslas: nustatyti paauglių mitybos ipročius bei palyginti tarp lyčių ir skirtingo fizinio aktyvumo moksleiviu grupių.

Metodai. Buvo tiriami devintų klasių mokiniai iš 16 Kauno miesto mokyklų (4 gimnazijų, 10 vidurinių ir 2 pagrindinių mokyklų). Parenkant tiriamuosius buvo stengiamasi įvertinti proporcijas tarp skirtingo tipo mokyklu Kauno mieste. Tyrimas atliktas naudojant anketinę apklausa.

Rezultatai. Atlikus analizę išsiaiškinta, kad net $28,5 \%$ moksleivių nevalgo pusryčių. Tarp jų daugiau mergaičių. Berniukai ir mažesnio fizinio aktyvumo moksleiviai pusryčiams dažniau renkasi šiltą maistą. Paaugliai dažniausiai valgo per parą keturis kartus, bet nesilaiko mitybos režimo.

Išvados ir perspektyvos. Berniukai dažniau valgo pusryčius, o užkandžiaudami renkasi bandeles, traškučius, daugiau vartoja keptų produktų. Taip pat elgiasi ir mažesnio fizinio aktyvumo moksleiviai. Mergaitės užkandžiaudamos linkusios dažniau valgyti vaisių, žalių daržovių. Dauguma moksleivių maistą renkasi pagal skoni, berniukai dažniau pagal kainą ir sveikatingumą. Daugiausia informacijos apie sveiką mitybą paaugliai gauna iš tėvų ir interneto, mergaitès daugiau iš žurnalų ir interneto nei berniukai.

Raktažodžiai: paauglių žinios apie sveiką mitybą, mitybos ipročiai, fizinis aktyvumas.

Gauta 2011 m. Kovo 15 d.

Received on March 15, 2011

Priimta $2011 \mathrm{~m}$. birželio $16 \mathrm{~d}$.

Accepted on June 16, 2011

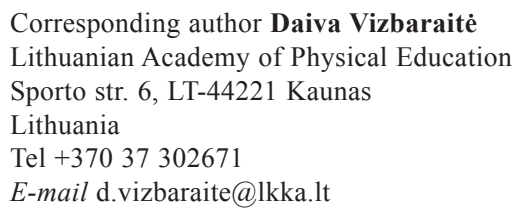

